\title{
Value investing or investing in illiquidity? The profitability of contrarian investment strategies, revisited
}

\author{
Aron A. Gottesman ${ }^{1}$, Gady Jacoby ${ }^{2}$ and Huijing Li $^{2^{*}}$
}

\footnotetext{
* Correspondence: umli434@myumanitoba.ca

${ }^{2}$ Department of Accounting and Finance, I. H. Asper School of Business, University of Manitoba, R3T5V4, Winnipeg, MB, Canada Full list of author information is available at the end of the article
}

\begin{abstract}
Background: We investigate whether the success of contrarian investment strategies can be attributed to differences in the relative illiquidity of stocks categorized as value investments versus those categorized as glamour portfolios.

Methods: Following Lakonishok et al. (J Financ 49:1541-1578, 1994), we assess the illiquidity characteristics of portfolios that underlie contrarian investment strategies that are based on the level of stock's book to market.

Results: We find strong evidence that those portfolios characterized as value investments are associated with dramatically greater levels of illiquidity than glamour portfolios. We further demonstrate that strategies based on the illiquidity in the year prior to portfolio formation result in return characteristic of ostensibly contrarian strategies.

Conclusions: These results suggest that the higher returns associated with contrarian investment strategies are the result of the higher illiquidity associated with value portfolios and represent compensation that the investor receives for accepting illiquidity. They also suggest that researchers should be cautious before attributing apparent anomalies to behavior-driven expectational errors rather than to other attributes unrelated to behavior, such as illiquidity.
\end{abstract}

Keywords: Contrarian investment strategies, Illiquidity, Value portfolios, Growth portfolios, Book to market ratio

\section{Background}

An extensive body of academic literature investigates the performance of contrarian investment strategies. Contrarian investment strategies refer to trading strategies in which stocks are classified as underpriced (value) or overpriced (glamour) based on relative past returns or accounting data. By investing in value stocks or divesting glamour stocks, advocates argue, investors can outperform the market. Generally, significant empirical evidence indicates that contrarian strategies outperform the market both in U.S. markets (De Bondt and Thaler, 1985, 1987; La Porta, 1996; La Porta et al. 1997; Lakonishok et al. 1994; Lettau and Wachter, 2007; Chen et al. 2008) and non-U.S. markets (Chan et al. 1991; Lai et al. 2003; Chin et al. 2002). Debate persists, however, as to whether the success of these contrarian strategies is due to expectational errors on the part of market participants (De Bondt and Thaler, 1985; Lakonishok et al. 1994; La Porta et al. 1997; Piotroski and So, 2012), which in turn lead to underpricing and

(c) The Author(s). 2017 Open Access This article is distributed under the terms of the Creative Commons Attribution 4.0 International License (http://creativecommons.org/licenses/by/4.0/), which permits unrestricted use, distribution, and reproduction in any medium, provided you give appropriate credit to the original author(s) and the source, provide a link to the Creative Commons license, and indicate if changes were made. 
overpricing, or whether investing in value stocks is fundamentally riskier than investing in glamour stocks (see Fama and French, 1992; Chan, 1988; Chen and Zhang, 1998; Ball and Kothari, 1989; Petkova and Zhang, 2005; Cohen et al. 2009; Campbell et al. 2010).

Petkovaa and Zhang (2005) find that the return differential between value and glamour portfolios can be partially attributed to time-varying risk. However, fundamental betas are lower in value portfolios than in growth portfolios (Lakonishok et al., 1994; Cohen et al., 2009). By contrast, Piotroski and So (2012) document that expectation errors play an important role in explaining the value premium in contrarian investment strategies, and provide evidence consistent with mispricing explanation.

The purpose of this study is to investigate whether the success of contrarian investment strategies can be attributed to differences in the relative illiquidity of stocks categorized as value versus those categorized as glamour. The motivation for considering illiquidity is the extensive evidence that returns are positively related to the degree to which stocks are illiquid. In a seminal paper, Amihud and Mendelson (1986) develop a model and empirical tests to demonstrate that asset returns are positively related to their proxy for illiquidity, that is, the relative bid-ask spread. Other evidence supports and explores these findings (e.g., see Amihud and Mendelson, 1989; Eleswarapu, 1997; Jacoby et al. 2000; Gottesman and Jacoby, 2006).

In this paper, we follow Lakonishok et al. (1994) and examine the illiquidity characteristics of value and growth portfolios. We investigate whether differences in the relative illiquidity of value portfolios versus glamour portfolios contribute to the success of contrarian investment strategies. Our evidence suggests that value portfolios are associated with dramatically greater levels of illiquidity than glamour portfolios. We further demonstrate that strategies based on illiquidity (in the year prior to portfolio formation), result in return characteristic of resembling contrarian strategies. Our results suggest that higher returns associated with contrarian investment strategies serve as a compensation for illiquidity associated with value portfolios.

The rest of this paper is organized as follows. Section II describes the methodology. Section III describes the results. Section IV concludes.

\section{Methods}

The portfolio formation and stock return estimation methodology used in this paper closely follows Lakonishok et al. (1994). We implemented this methodology using American Stock Exchange (AMEX) and New York Stock Exchange (NYSE) stock data from the period May 1967 through April 2005, extracted from the Center for Research in Security Prices (CRSP) database. Because 1 year of preportfolio formation data is required to form the portfolio, and because postportfolio formation returns are estimated for a five-year period, we formed portfolios for the years 1968 through 2000, for a total of 33 separate test years.

Portfolio formation takes place at the end of April of every test year by identifying stocks for which monthly market value data are available for April of the test year and for which book value data, extracted from the COMPUSTAT database, are available for the fiscal year prior to the test year. We calculated book to market as the book value of the stock for the fiscal year prior to the test year divided by the market value of the stock for April of the test year. 
We extracted returns from CRSP for the 60-month period beginning in the month of May immediately following portfolio formation and ending April of the fifth year following portfolio formation. We calculated annual return using these monthly returns for May through April of each of the five postportfolio formation years.

If monthly returns for a given stock disappears for a given stock during any month in a given postportfolio formation year (May through April), we assumed that the investor invested in a randomly chosen stock with similar market capitalization for the remainder of the year (i.e., until the end of April). To determine the expected return value of this random choice, we implemented the following procedure separately for each of the 33 test years, following Lakonishok et al. (1994): For April of each of the 5 years postportfolio formation, the market value of stocks for which monthly return is available for April of the given year is extracted from CRSP. All stocks for which market value is available for April of the given year then are ranked on the basis of their market value and are placed into 10 groups based on their ranking. For each of the market value groups identified in April of each year, the equally weighted average non-missing monthly return of all stocks within each market value group is estimated for the subsequent 12-month period. Then, for every stock for which a ranking is available in April of the given year and for which a monthly return is unavailable during any of the subsequent 12 months, any missing monthly return is specified as the average return for the stock's market capitalization group.

The illiquidity measure used in this paper is the ILLIQ measure from Amihud (2002), normalized following a method similar to the one described by Acharya and Pedersen (2005). As specified in Amihud's Eq. (1), ILLIQiy is calculated as follows for each stock $i$ of year $y$ as follows:

$$
I L L I Q_{i y}=\frac{1}{D_{i y}} \sum_{t=1}^{D i y} \frac{\left|R_{i y d}\right|}{V O L D_{i y d}},
$$

where Diy is the numbers of days for which trading data are available during the given year for each stock $i$ of year $y$; Riyd is the return for stock $i$ on day $d$ of year $y$; and $V O L D i y d$ is dollar volume for stock $i$ on day $d$ of year $y$. To permit comparison across years, we normalized the illiquidity measure using a method that is similar (but not identical) to Acharya and Pedersen [2005, Eq. (18)]. Let CAPRATIOy be the ratio of equally weighted average monthly market capitalization for year $y$ to the equally weighted average monthly market capitalization for the year 1967 . We then calculate normalized illiquidity, designated NILLIQiy, as follows:

$$
N I L L I Q_{i y}=\min \left(0.25+0.30 \cdot I_{L L I Q_{i y}} \cdot C A P R A T I O_{y}, 30.00\right)
$$

The NILLIQiy value for each stock is estimated for the subsequent five postportfolio formation years, separately for each of the 33 test years, for all stocks for which at least 100 daily return observations are identifiable between May and April for the given postportfolio formation year. If monthly returns for a given stock disappear during any month in a given postportfolio formation year, then the NILLIQiy value for the stock is the average of the NILLIQiy value for the stock and the NILLIQiy value for the corresponding market value group, where the weight given to each NILLIQiy value in the 
averaging is based on the proportion of months for which the stock return is available during the given year.

On the basis of this methodology, the following data are available for each of the 33 test years: 5 years of postportfolio formation annual returns (adjusted to control for survivorship); 5 years of postportfolio formation annual normalized illiquidity values (adjusted to control for survivorship); and preportfolio formation book to market.

\section{Results}

For each of the 33 test years described in the previous section, we ranked stocks on the basis of preportfolio formation book to market, and subsequently, we placed each stock into 1 of 10 book-to-market groups. We then calculated the average return and average normalized illiquidity for each postportfolio formation year, for each of the 10 book-tomarket groups. Additionally, we calculated the average and cumulative returns over the five-year postportfolio formation period for each of the 10 book-to-market groups. Table 1 presents the results of the return averaging across all 33 test years in the sample, and Table 2 presents the results of the illiquidity averaging.

The results presented in Table 1 are broadly similar to Lakonishok et al. (1994), although the sample period in this test is 1968-2000, whereas Lakonishok et al.'s (1994) sample period is 1968-1989. Average and cumulative returns increase as the book-to-market ratio increases. In Table 1, cumulative returns range from 0.6908 to 1.4553 , whereas in Lakonishok et al.'s (1994) work, cumulative returns range from 0.560 through 1.462. Our results indicate that returns monotonically increase as book to market increases, with the exception of returns associated with the highest book-to-market group, which are lower than the second-highest book-to-market group. Overall, these results indicate that the contrarian investment strategy described by Lakonishok et al. (1994) using 1968-1989 data continues to result in clear value-growth differences over the longer 1968-2000 period.

Table 1 Average returns, book-to-market portfolios. Ten portfolios are formed using book-to-market data at the end of April for each year in the 33-year period between 1968 through 2000 for all AMEX and NYSE stocks identified on CRSP, following the methodology detailed in Lakonishok et al. (1994). For each year, returns are extracted for the subsequent 60-month period. Annual return is then calculated using these monthly returns for May through April of each of the five post-portfolio formation years. If a stocks monthly returns disappear then the investor is assumed to invest for the remainder of the year in a randomly chosen stock within the same decile grouping on the basis of market capitalization. Book-to-market is calculated as the book value of the stock for the fiscal year prior to the test year divided by the market value of the stock for April of the test year. The average values across the 33 years in the sample of the annual returns are reported in this table for each of the five post-portfolio formation years. As well, the average annual return and cumulative return are reported for each book-to-market group. "Glamour" and "Value" refer to the groups with the lowest and highest values of book-to-market, respectively

\begin{tabular}{lllllllllll}
\hline & Glamour & & & & & & & & Value \\
& BM1 & BM2 & BM3 & BM4 & BM5 & BM6 & BM7 & BM8 & BM9 & BM10 \\
\hline Average return, year 1 & 0.1215 & 0.1453 & 0.1368 & 0.1398 & 0.1457 & 0.1630 & 0.1685 & 0.1741 & 0.1826 & 0.1756 \\
Average return, year 2 & 0.0906 & 0.1292 & 0.1333 & 0.1566 & 0.1580 & 0.1651 & 0.1809 & 0.1857 & 0.1972 & 0.1910 \\
Average return, year 3 & 0.0990 & 0.1333 & 0.1478 & 0.1472 & 0.1636 & 0.1669 & 0.1705 & 0.1914 & 0.1991 & 0.1774 \\
Average return, year 4 & 0.1259 & 0.1319 & 0.1528 & 0.1599 & 0.1790 & 0.1755 & 0.1804 & 0.2058 & 0.2028 & 0.2011 \\
Average return, year 5 & 0.1173 & 0.1369 & 0.1539 & 0.1680 & 0.1709 & 0.1815 & 0.2027 & 0.2019 & 0.2025 & 0.2076 \\
Average annual return & 0.1108 & 0.1353 & 0.1449 & 0.1543 & 0.1634 & 0.1704 & 0.1806 & 0.1918 & 0.1968 & 0.1905 \\
Cumulative return & 0.6908 & 0.8862 & 0.9671 & 1.0489 & 1.1310 & 1.1961 & 1.2931 & 1.4038 & 1.4553 & 1.3911 \\
\hline
\end{tabular}


Table 2 Average normalized illiquidity, book-to-market portfolios. Ten portfolios are formed using book-to-market data at the end of April for each year in the 33-year period between 1968 through 2000 for all AMEX and NYSE stocks identified on CRSP, following the methodology detailed in Lakonishok et al. (1994). For each year for each stock in each portfolio, Amihud (2002)'s illiquidity measure is estimated for each stock for which 100 trading observations are identified, as:

$I L L I Q_{i y}=\frac{1}{D_{i y}} \sum_{t=1}^{D i y} \frac{\left|R_{i y d}\right|}{V O L D_{i y d}}$, where $D_{i y}$ is the numbers of days for which trading data is available during the given year for each stock $i$ of year $y_{i} R_{i y d}$ is the return for stock $i$ on day $d$ of year $y$, and $V O L D_{i y d}$ is dollar volume for stock $i$ on day $d$ of year $y$. This measure is then normalized using a methodology similar to Acharya and Pedersen (2005), as follows: NILLIQ $Q_{i y}=\min \left(0.25+0.30 \cdot I L L I Q_{i y} \cdot\right.$ CAPRATIO, 30.00$)$, where CAPRATIO is the ratio of equally weighted average monthly market capitalization for year $y$ to the equally weighted average monthly market capitalization for the year 1967. If monthly returns for a given stock disappears for a given stock during any month in a given post-portfolio formation year, then the $N I L L I Q_{i y}$ value for the stock is the average of the $N I L L I Q_{i y}$ value for the stock and the $N I L L I Q_{i y}$ value for the corresponding market value group, where the weight given to each $N I L L I Q_{i y}$ value in the averaging is based on the proportion of months for which the stock return is available during the given year. The average values across the 33 years in the sample of the annual normalized illiquidity are reported in this table for each of the five post-portfolio formation years. As well, the average annual normalized illiquidity is reported as well. "Glamour" and "Value" refer to the groups with the lowest and highest values of book-to-market, respectively

\begin{tabular}{lllllllllll}
\hline & Glamour & & & & & & & & & Value \\
& BM1 & BM2 & BM3 & BM4 & BM5 & BM6 & BM7 & BM8 & BM9 & BM10 \\
\hline Average NILLIQ, year 1 & 2.3882 & 1.1523 & 1.1793 & 1.2989 & 1.4233 & 1.5981 & 1.9833 & 2.6994 & 3.7825 & 5.4139 \\
Average NILLIQ, year 2 & 2.3505 & 1.3134 & 1.3123 & 1.4704 & 1.5427 & 1.7334 & 2.1477 & 2.8024 & 4.0666 & 5.4116 \\
Average NILLIQ, year 3 & 2.4248 & 1.4867 & 1.4259 & 1.5435 & 1.6282 & 1.8834 & 2.2900 & 2.8887 & 4.1540 & 5.3129 \\
Average NILLIQ, year 4 & 2.4672 & 1.5527 & 1.4781 & 1.6050 & 1.6729 & 1.8696 & 2.2568 & 2.8918 & 4.1206 & 5.1171 \\
Average NILLIQ, year 5 & 2.4921 & 1.6167 & 1.4583 & 1.6484 & 1.6716 & 1.8711 & 2.2359 & 2.7667 & 4.0694 & 4.7968 \\
Average annual NILLIQ & 2.4246 & 1.4244 & 1.3708 & 1.5132 & 1.5877 & 1.7911 & 2.1828 & 2.8098 & 4.0386 & 5.2105 \\
\hline
\end{tabular}

The results presented in Table 2, however, strongly suggest that those portfolios characterized as value and growth by Lakonishok et al. (1994) differ considerably in their illiquidity. The average annual normalized illiquidity ranges from 1.3708 to 5.2105 , with the level of the illiquidity measure increasing as book to market increases. The illiquidity measure increases monotonically beginning with the third-lowest book-to-market group, although illiquidity is higher for the two-lowest book-to-market groups than it is for the third-lowest book-to-market group. Figure 1 presents a graph of illiquidity and average returns across the 10 portfolios. This graph illustrates the dramatic differences in illiquidity across portfolios.

To further test whether illiquidity can explain return differences across portfolios, we next form portfolios on the basis of normalized illiquidity. Portfolio formation takes place at the end of April of every test year by identifying stocks for which normalized illiquidity for the preportfolio formation year is available. Proceeding as described earlier, we extract returns for each stock and adjust for survivorship. For each of the 33 test years, we then rank stocks on the basis of preportfolio formation normalized illiquidity, and subsequently, we place each stock into 1 of 10 (normalized) illiquidity groups. We then calculate the average return for each postportfolio formation year, for each of the 10 illiquidity groups. Additionally, we calculate the average and cumulative returns over the five-year postportfolio formation period for each of the 10 illiquidity groups. 


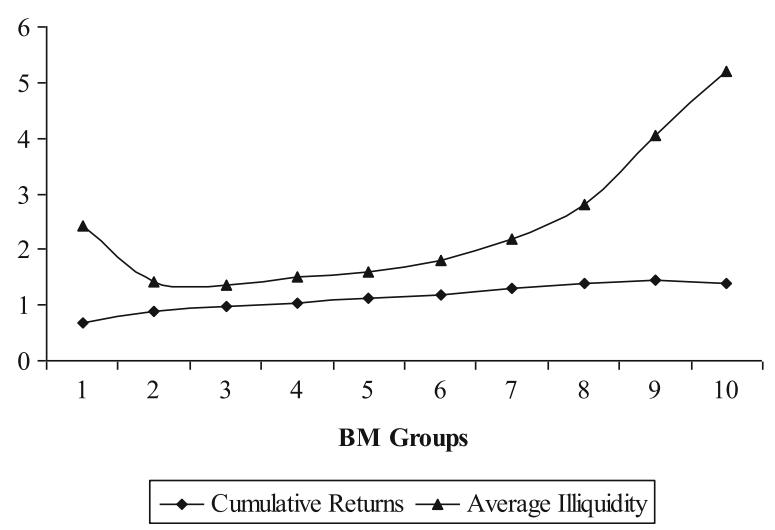

Fig. 1 Plot of cumulative returns and average normalized illiquidity for 10 book to market groups. Portfolios are formed using book-to-market data at the end of April for each year in the 33-year period between 1968 through 2000 for all AMEX and NYSE stocks identified on CRSP

Table 3 presents the results of the return averaging across all 33 test years in the sample. The results presented in Table 3 demonstrate a close relation between illiquidity and returns. Cumulative returns range from 0.8772 to 1.7310 , increasing monotonically as illiquidity increases. These results indicate that forming portfolios on the basis of illiquidity results in return patterns similar to those of contrarian investment strategies. These results, combined with the evidence that illiquidity is positively related to book to market, suggest that illiquidity can explain the superior returns associated with contrarian investment strategies.

Table 3 Average returns, normalized illiquidity portfolios. Ten portfolios are formed using normalized illiquidity for the pre-portfolio formation year ending in April for each year in the 33-year period between 1968 through 2000 for all AMEX and NYSE stocks identified on CRSP. For each year, returns are extracted for the subsequent 60-month period. Annual return is then calculated using these monthly returns for May through April of each of the five post-portfolio formation years. If a stocks monthly returns disappear then the investor is assumed to invest for the remainder of the year in a randomly chosen stock within the same decile grouping on the basis of market capitalization. The normalized illiquidity, NILLIQ, is calculated using the methodology detailed in the description of Table 2. The average values across the 33 years in the sample of the annual returns are reported in this table for each of the five post-portfolio formation years. As well, the average annual return and cumulative return are reported for each normalized illiquidity group

\begin{tabular}{lllllllllllll}
\hline & Low & NILLIQ & & & & & & & High & NILLIQ \\
& NILLIQ1 & NILLIQ2 & NILLIQ3 & NILLIQ4 & NILLIQ5 & NILLIQ6 & NILLIQ7 & NILLIQ8 & NILLIQ9 & NILLIQ10 \\
\hline $\begin{array}{l}\text { Average return, } \\
\text { year 1 }\end{array}$ & 0.1318 & 0.1373 & 0.1439 & 0.1423 & 0.1460 & 0.1471 & 0.1525 & 0.1620 & 0.1771 & 0.2161 \\
$\begin{array}{l}\text { Average return, } \\
\text { year 2 }\end{array}$ & 0.1324 & 0.1412 & 0.1400 & 0.1455 & 0.1490 & 0.1609 & 0.1628 & 0.1696 & 0.1765 & 0.2188 \\
$\begin{array}{l}\text { Average return, } \\
\text { year 3 }\end{array}$ & 0.1297 & 0.1387 & 0.1445 & 0.1343 & 0.1630 & 0.1534 & 0.1817 & 0.1719 & 0.1801 & 0.2115 \\
$\begin{array}{l}\text { Average return, } \\
\text { year 4 }\end{array}$ & 0.1375 & 0.1411 & 0.1465 & 0.1555 & 0.1819 & 0.1795 & 0.1776 & 0.1834 & 0.1922 & 0.2380 \\
$\begin{array}{l}\text { Average return, } \\
\text { year 5 }\end{array}$ & 0.1398 & 0.1433 & 0.1436 & 0.1684 & 0.1778 & 0.1924 & 0.1786 & 0.1944 & 0.1972 & 0.2285 \\
$\begin{array}{l}\text { Average } \\
\text { annual return } \\
\begin{array}{l}\text { Cumulative } \\
\text { return }\end{array}\end{array}$ & 0.1342 & 0.1403 & 0.1437 & 0.1492 & 0.1636 & 0.1667 & 0.1706 & 0.1763 & 0.1846 & 0.2226 \\
\hline
\end{tabular}


To further explore the role of illiquidity in explaining superior returns from contrarian investment strategies, we next calculate annual differences in average return and illiquidity for value and glamour portfolios for each year in our sample period: 1968-2000. To control for any year-specific illiquidity effects, we present differences in illiquidity on a percentage basis. We calculate differences across the three types of portfolio groupings: (1) the difference between the five highest and five lowest book-to-market groups; (2) the difference between the three highest and three lowest book-to-market groups; and (3) the difference between the highest and lowest book-to-market groups. The results presented are for the subsequent five-year postportfolio formation period.

The results, presented in Table 4, clearly demonstrate that higher book-to-market groups earned superior returns relative to lower book-to-market groups during the vast majority of years, for all three types of portfolio groupings (Table 4, Panel A). For both the five (5 highest BM groups- 5 lowest BM groups) and three (3 highest BM groups-3 lowest BM groups) portfolio group differences, the exception is the period from 1987 to 1989, during which lower book-to-market groups experienced superior returns. For the one portfolio group differences (highest BM groups-5 lowest BM groups), the exception is 2 years: 1988 and 1999, during which lower book-to-market groups experienced superior returns.

Correspondingly, the results presented in Table 4, Panel B, indicate that illiquidity is higher for the higher book-to-market portfolio relative to the lower book-to-market portfolio, for all three types of portfolio groupings, without exception.

Fig. 2 plots the annual average return differences and annual percentage differences in illiquidity for the five highest and lowest (Fig. 2, Panel A), three highest and lowest (Fig. 2, Panel B), and highest and lowest (Fig. 2, Panel C) portfolio groups. These figures seem to indicate a relation between the degree of annual percentage differences in illiquidity and differences in annual average returns. For example, visual inspection suggests a period of elevated differences in annual average returns and annual average differences in illiquidity during the 1970s.

To confirm this relation, we next perform multivariate estimation of the relation between illiquidity and returns. We perform five ordinary least squares (OLS) regressions, presented in Table 5 in columns (a) through (e). Regressions (a), (b), and (c) relate the differences in annual average returns and percentage differences in annual illiquidity for the five highest and lowest, three highest and lowest, and highest and lowest portfolio groupings, respectively. Regressions (d) and (e) relate return and illiquidity across the following two samples: for regression (d), a sample of 50 observations, consisting of the 10 book-to-market groups for each of the five postportfolio formation years, averaged over the 33 years in our sample period; and for regression (e), a sample that consists of the aggregate of all of the observations underlying each of the 33 years in our sample period. Although the sample tested in regression (e) is very large, it is also very noisy because it lacks portfolio formation.

The results presented in Table 5 provide further evidence of a positive relation between the superior returns associated with contrarian investment strategies and illiquidity. For all regressions, evidence is strong of a positive relation between returns and illiquidity, significant at the $1 \%$ level. The regression results also indicate that return differences decreased over time and that average annual returns increased as the number of years postportfolio formation increased. 
Table 4 Annual differences in average return and illiquidity for value and glamour portfolios. The difference in average return and the percentage difference in illiquidity is reported for each year in the sample period 1968-2000. The average return value is the annual average return over the 5 year post-portfolio formation period. The average illiquidity value is the annual average normalized illiquidity over the 5 year post-portfolio formation period. Both measures are reported for the difference between the five, three, and single highest and lowest BM groups

\begin{tabular}{|c|c|c|c|}
\hline \multirow[t]{2}{*}{ Year } & 5 highest BM groups - & 3 highest BM groups - & Highest BM group - \\
\hline & 5 lowest BM groups & 3 lowest BM groups & Lowest BM group \\
\hline \multicolumn{4}{|c|}{ Panel A: Difference in average return } \\
\hline 1968 & 0.0348 & 0.0483 & 0.0554 \\
\hline 1969 & 0.0363 & 0.0502 & 0.0552 \\
\hline 1970 & 0.0339 & 0.0485 & 0.0637 \\
\hline 1971 & 0.0491 & 0.0664 & 0.0790 \\
\hline 1972 & 0.0799 & 0.1241 & 0.1659 \\
\hline 1973 & 0.0863 & 0.1159 & 0.1329 \\
\hline 1974 & 0.1029 & 0.1437 & 0.2001 \\
\hline 1975 & 0.0934 & 0.1396 & 0.1688 \\
\hline 1976 & 0.0661 & 0.0974 & 0.1221 \\
\hline 1977 & 0.0498 & 0.0797 & 0.0770 \\
\hline 1978 & 0.0473 & 0.0436 & 0.0396 \\
\hline 1979 & 0.0517 & 0.0581 & 0.0988 \\
\hline 1980 & 0.0914 & 0.1537 & 0.2028 \\
\hline 1981 & 0.1296 & 0.1758 & 0.2630 \\
\hline 1982 & 0.0976 & 0.1236 & 0.1967 \\
\hline 1983 & 0.0563 & 0.0730 & 0.0878 \\
\hline 1984 & 0.0314 & 0.0528 & 0.1237 \\
\hline 1985 & 0.0145 & 0.0272 & 0.0594 \\
\hline 1986 & 0.0042 & 0.0114 & 0.0374 \\
\hline 1987 & $(0.0042)$ & $(0.0014)$ & 0.0456 \\
\hline 1988 & $(0.0015)$ & $(0.0167)$ & $(0.0511)$ \\
\hline 1989 & $(0.0013)$ & $(0.0051)$ & 0.0055 \\
\hline 1990 & 0.0338 & 0.0546 & 0.0859 \\
\hline 1991 & 0.0463 & 0.0734 & 0.0624 \\
\hline 1992 & 0.0507 & 0.0770 & 0.0757 \\
\hline 1993 & 0.0434 & 0.0606 & 0.0612 \\
\hline 1994 & 0.0288 & 0.0427 & 0.0277 \\
\hline 1995 & 0.0067 & 0.0116 & 0.0184 \\
\hline 1996 & 0.0393 & 0.0479 & 0.1053 \\
\hline 1997 & 0.0053 & 0.0108 & 0.0193 \\
\hline 1998 & 0.0179 & 0.0330 & 0.0101 \\
\hline 1999 & 0.0285 & 0.0259 & $(0.0013)$ \\
\hline 2000 & 0.0805 & 0.1106 & 0.0657 \\
\hline \multicolumn{4}{|c|}{ Panel B: Percentage difference in average illiquidity } \\
\hline 1968 & 0.1144 & 0.2146 & 0.7260 \\
\hline 1969 & 0.1431 & 0.1184 & 0.2123 \\
\hline 1970 & 0.7722 & 1.0185 & 1.3674 \\
\hline 1971 & 0.6590 & 0.9726 & 1.2666 \\
\hline
\end{tabular}


Table 4 Annual differences in average return and illiquidity for value and glamour portfolios. The difference in average return and the percentage difference in illiquidity is reported for each year in the sample period 1968-2000. The average return value is the annual average return over the 5 year post-portfolio formation period. The average illiquidity value is the annual average normalized illiquidity over the 5 year post-portfolio formation period. Both measures are reported for the difference between the five, three, and single highest and lowest BM groups (Continued)

\begin{tabular}{|c|c|c|c|}
\hline Year & 5 highest BM groups - & 3 highest BM groups - & Highest BM group - \\
\hline & 5 lowest BM groups & 3 lowest BM groups & Lowest BM group \\
\hline 1972 & 0.6900 & 0.9773 & 1.7456 \\
\hline 1973 & 1.4859 & 2.8996 & 3.6753 \\
\hline 1974 & 2.0165 & 3.7844 & 5.3174 \\
\hline 1975 & 1.9852 & 4.0379 & 5.4605 \\
\hline 1976 & 1.6258 & 2.8719 & 3.5562 \\
\hline 1977 & 2.1408 & 3.2055 & 3.0029 \\
\hline 1978 & 1.5290 & 2.3012 & 2.1092 \\
\hline 1979 & 1.5027 & 2.2197 & 3.0403 \\
\hline 1980 & 1.7339 & 2.4542 & 2.9349 \\
\hline 1981 & 1.2422 & 2.0068 & 2.3274 \\
\hline 1982 & 1.1650 & 1.5370 & 1.9587 \\
\hline 1983 & 0.3510 & 0.6076 & 0.5071 \\
\hline 1984 & 0.3617 & 0.5018 & 0.3503 \\
\hline 1985 & 0.5552 & 0.6694 & 0.4570 \\
\hline 1986 & 0.4760 & 0.6537 & 0.4371 \\
\hline 1987 & 0.5662 & 0.6578 & 0.4516 \\
\hline 1988 & 0.7981 & 1.0575 & 0.6920 \\
\hline 1989 & 0.8275 & 1.1227 & 0.7630 \\
\hline 1990 & 1.0307 & 1.4029 & 0.9643 \\
\hline 1991 & 1.1522 & 1.4336 & 0.9256 \\
\hline 1992 & 0.8748 & 1.0944 & 0.9229 \\
\hline 1993 & 0.8950 & 1.1955 & 0.9548 \\
\hline 1994 & 0.6319 & 0.9312 & 0.8464 \\
\hline 1995 & 0.7382 & 1.2047 & 1.1497 \\
\hline 1996 & 0.6797 & 0.9123 & 0.7582 \\
\hline 1997 & 0.8641 & 1.1579 & 0.8753 \\
\hline 1998 & 0.8544 & 1.2579 & 1.4663 \\
\hline 1999 & 1.3943 & 2.1770 & 1.5087 \\
\hline 2000 & 1.1868 & 1.5958 & 1.1139 \\
\hline
\end{tabular}

Finally, evidence shows a positive relation between book to market and returns, suggesting that book to market may influence returns for reasons beyond illiquidity. The adjusted $R^{2}$ associated with the regressions varies greatly depending on the type of regression performed. For regressions (a) through (c), the adjusted $R^{2}$ ranges from 0.3596 to 0.3895 . For regression (e), the adjusted $R^{2}$ is 09190 , and for regression (e), consisting of noisy raw stock returns and illiquidity, the adjusted $R^{2}$ is very low, at 0.0024 . These results present further confirmation that the success of contrarian investment strategies is primarily driven by illiquidity differences rather than by behavioral or risk explanations. 


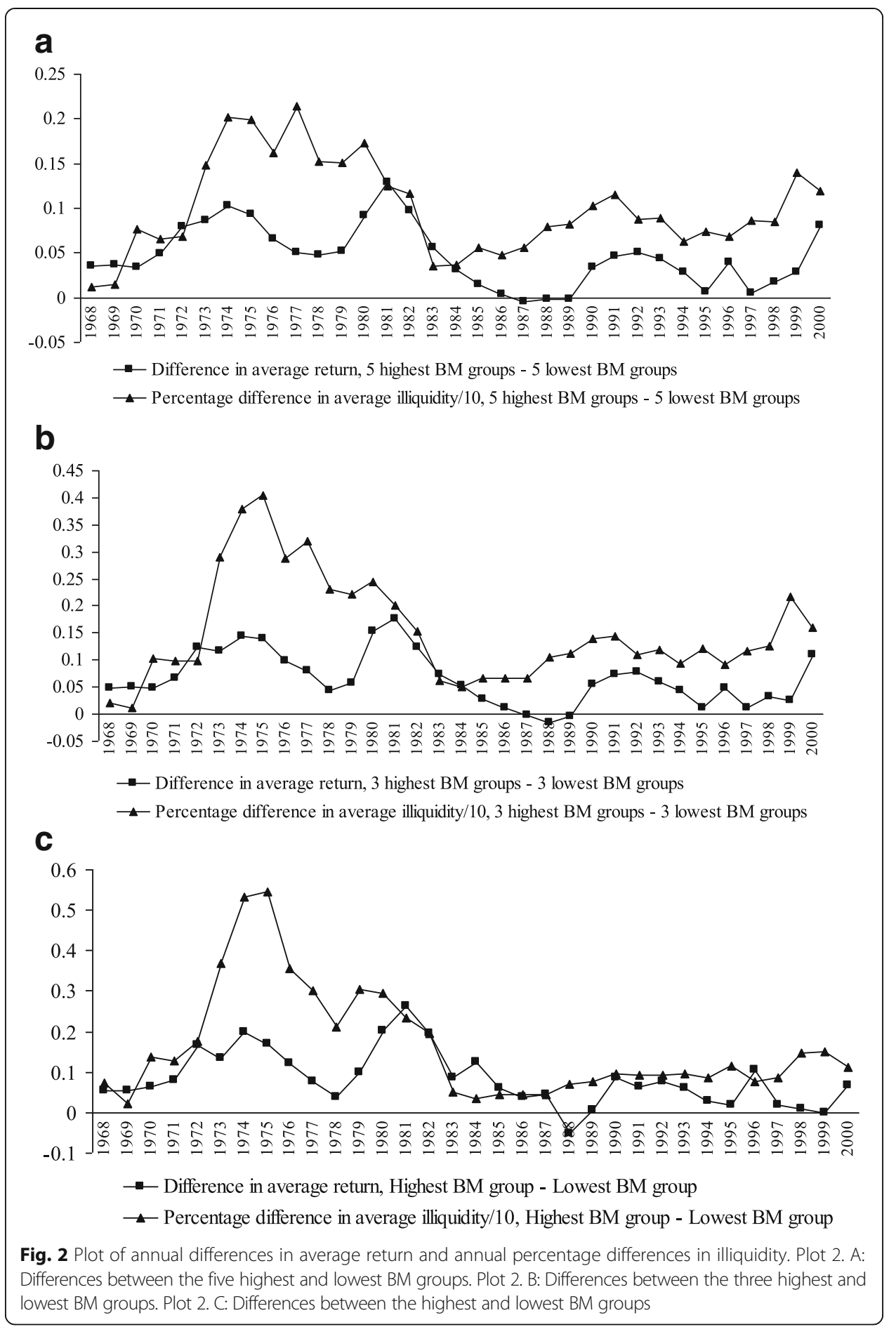

\section{Discussion}

In this paper, we find strong evidence that those portfolios characterized as "value" investments are associated with dramatically greater levels of illiquidity than "glamour" portfolios. The results suggest that researchers should exercise caution before attributing apparent anomalies to behavior-driven expectational errors rather than to other rational attributes unrelated to behavior, such as illiquidity. 
Table 5 Regression analysis: OLS regressions are performed for five samples: (a) Sample of differences across the five highest and five lowest BM groups for the variables average post-portfolio formation returns and normalized illiquidity; (b) Same as (a), for the three highest and three lowest BM groups; (c) Same as (a), for the highest and lowest BM groups; (d) Sample of average annual returns and illiquidity across BM groups and post-portfolio formation years; (e) Sample of annual returns for each stock for each post-portfolio formation year

\begin{tabular}{|c|c|c|c|c|c|}
\hline & (a) & (b) & (c) & (d) & (e) \\
\hline & $\begin{array}{l}\text { Five highest/lowest BM } \\
\text { group average return } \\
\text { annual difference }\end{array}$ & $\begin{array}{l}\text { Three highest/lowest } \\
\text { BM group average } \\
\text { annual return difference }\end{array}$ & $\begin{array}{l}\text { Highest/lowest BM } \\
\text { group average } \\
\text { annual return } \\
\text { difference }\end{array}$ & $\begin{array}{l}\text { Average } \\
\text { annual } \\
\text { return, } 10 \mathrm{BM} \\
\text { groups }\end{array}$ & $\begin{array}{l}\text { Annual } \\
\text { return, all } \\
\text { stocks }\end{array}$ \\
\hline Intercept & $2.4089^{* *}$ & $2.9429^{* *}$ & 3.5226 & $0.1153^{* * *}$ & $0.1074^{* * *}$ \\
\hline Illiquidity & $0.03316^{* * *}$ & $0.0257^{* * *}$ & $0.0247^{* * *}$ & $0.0077^{* * *}$ & $0.0019^{* * *}$ \\
\hline BM group & & & & $0.0114^{* * *}$ & $0.0082^{* * *}$ \\
\hline Nominal year & & & & $0.0054^{* * *}$ & $0.0050^{* * *}$ \\
\hline Year & $-0.0012^{* *}$ & $-0.0015^{* *}$ & -0.0018 & & \\
\hline Adj-R2 & 0.3895 & 0.3779 & 0.3596 & 0.9190 & 0.0024 \\
\hline Observations & 33 & 33 & 33 & 50 & 327,960 \\
\hline
\end{tabular}

***, and $* *$ denote significance at the $1 \%$ and $5 \%$ levels

\section{Conclusions}

This study investigates whether the success of contrarian investment strategies is due to differences in the relative illiquidity of value portfolios versus glamour portfolios. We examine illiquidity characteristics of portfolios that underlie contrarian investment strategies (based on Lakonishok et al., 1994). Our evidence for these portfolios indicates that superior returns are positively associated with contrarian investment strategies and illiquidity. The results suggest that the higher returns associated with contrarian investment strategies are the result of the higher illiquidity associated with value portfolios. In other words, investors are compensated with higher returns for facing illiquidity.

Acknowledgements

Jacoby acknowledges the financial support from Bryce Douglas Professorship in Finance and the Social Sciences and Humanities Research Council of Canada.

Funding

Not applicable.

Authors' contributions

GJ and AG proposed to link the contrarian investing strategies and stock illiquidity, performed the statistical analysis and drafted the manuscript. HL reviewed the literature and helped to draft the manuscript. All authors read and approved the final manuscript.

Competing interests

The authors declare that they have no competing interests.

\section{Publisher's Note}

Springer Nature remains neutral with regard to jurisdictional claims in published maps and institutional affiliations.

\section{Author details}

'Department of Finance, Lubin School of Business, Pace University, One Pace Plaza, New York, NY 10038, USA. ${ }^{2}$ Department of Accounting and Finance, I. H. Asper School of Business, University of Manitoba, R3T5V4, Winnipeg, MB, Canada. 
Received: 11 October 2017 Accepted: 14 November 2017

Published online: 09 December 2017

\section{References}

Acharya W, Pedersen LH (2005) Asset pricing with liquidity risk. J Financ Econ 77:375-410

Amihud Y (2002) Illiquidity and stock returns: cross-section and time-series effects. J Financ Mark 5:31-56

Amihud Y, Mendelson H (1986) Asset pricing and the bid-ask spread. J Financ Econ 17:223-249

Amihud Y, Mendelson H (1989) The effect of beta, bid-ask spread, residual risk and size on stock returns. J Financ 44:479-486

Ball R, Kothari SP (1989) Nonstationary expected returns: implications for tests of market efficiency and serial correlations in returns. J Financ Econ 25:51-74

Campbell J, Polk C, Vuolteenaho T (2010) Growth or glamour? fundamentals and systematic risk in stock returns. Rev Financ Stud 23:306-344

Chan KC (1988) On the contrarian investment strategy. J Bus 61:147-163

Chan KC, Hamao Y, Lakonishok J (1991) Fundamentals and stock returns in Japan. J Financ 46:1739-1764

Chen L, Petkova R, Zhang L (2008) The expected value premium. J Financ Econ 87:269-280

Chen N, Zhang F (1998) Risk and return of value stocks. J Bus 71:501-535

Chin JYF, Prevost AK, Gottesman AA (2002) Contrarian investing in a small cap market: evidence from New Zealand. Financ Rev 37:421-446

Cohen R, Polk C, Vuolteenaho T (2009) The price is (almost) right. J Financ 64:2739-2782

De Bondt W, Thaler R (1985) Does the stock market overreact? J Financ 40:793-805

De Bondt W, Thaler R (1987) Further evidence on investor overreaction and stock market seasonality. J Financ 42:557-581

Eleswarapu VR (1997) Cost of transacting and expected returns in the Nasdaq market. J Financ 52:2113-2127

Fama E, French K (1992) The cross-section of expected stock returns. J Financ 47:427-465

Gottesman AA, Jacoby G (2006) Payout policy, taxes, and the relation between returns and the bid-ask spread. J Bank Financ 30:37-48

Lai MM, Guru BK, Nor FM (2003) Do Malaysian investors overreact? J Am Acad Bus 2:602-610

Jacoby G, Fowler DJ, Gottesman AA (2000) The capital asset pricing model and the liquidity effect: a theoretical approach. J Financ Mark 3:69-81

La Porta R (1996) Expectation and the cross-section of stock returns. J Financ 51:1715-1742

La Porta R, Lakonishok J, Shleifer A, Vishny RW (1997) Good news for value stocks: further evidence on market efficiency. J Financ 52:859-874

Lakonishok J, Shleifer A, Vishny RW (1994) Contrarian investment, extrapolation, and risk. J Financ 49:1541-1578

Lettau M, Wachter J (2007) Why is long-horizon equity less risky? a duration-based explanation of the value premium. J Financ 62:55-92

Petkova R, Zhang L (2005) Is value riskier than growth? J Financ Econ 78:187-202

Piotroski JD, So EC (2012) Identifying expectation errors in value/flamour strategies: a fundamental analysis approach. Rev Financ Stud 25:2841-2875

\section{Submit your manuscript to a SpringerOpen ${ }^{\circ}$ journal and benefit from:}

- Convenient online submission

- Rigorous peer review

- Open access: articles freely available online

- High visibility within the field

- Retaining the copyright to your article 